International Journal of Engineering \& Technology, $7(2.13)(2018) 178-182$
SPC

\title{
The history of the development of Russian cultural volunteering: historical and contemporary practices
}

\author{
Gorlova N. I. ${ }^{1}$, Troska Z. A. ${ }^{2 *}$, Karpenko Ye. Z. ${ }^{2}$, Krutitskaya Ye. V. ${ }^{3}$, Min'kova N. O. ${ }^{4}$, Semin O. V. ${ }^{5}$ \\ ${ }^{1}$ Department of Management and Marketing sports industry, Plekhanov Russian University of Economics, Moscow \\ ${ }^{2}$ Department of Human Resource Management, Plekhanov Russian University of Economics, Moscow, Russia 15, \\ Sudakovast, Moscow, 109382, the Russian Federation \\ ${ }^{3}$ Department of Sociology and Management, Russian State Social University, Moscow, Russia \\ ${ }^{4}$ Department of advertising, marketing and public relations, Russian State Social University \\ ${ }^{5}$ Moscow State University of Psychology and Education
}

\begin{abstract}
The article presents a modern methodology for organizing the practical work of volunteers in the cultural sphere using the example of Russian cultural institutions. The used methodology allows to gain knowledge and practical experience of interaction with the target audience of cultural events, to explain the main features and principles of the volunteer movement in the sphere of culture; to use successful practices of organizing the volunteers' work in cultural institutions. Using surveys, interviews and personal conversations with active participants of the research and ongoing progress of developing cultural volunteering in Russia, it allowed to supplement the material received from various sources, which significantly increased the scientific quality of author's research. In addition, the article provides an analysis of research in personal characteristics of volunteers, a system of motivation and incentives and also identifies key areas of activity. Such approach in volunteer management is complex and universal, and therefore can be used with volunteers by various cultural institutions. The practical significance of the research is that its conclusions and recommendations can be successfully used in the recruiting, professional selection and support in training, retraining and analysis of volunteer activities in the field of culture.
\end{abstract}

Keywords: Volunteering; Cultural Volunteering; Volunteer Projects; Volunteerism; Volunteer Management; Cultural Institutions; Educational Projects; Museum Activities.

\section{Introduction}

Volunteer activity in cultural and art spheres is a voluntary assistance in support of cultural projects that is aimed at educating the world's population on the best art and is realized through the active personal involvement by volunteers. One of the priorities of the modern volunteer activities is doing them in different areas of the culture: cinema; museum activities; literary activity; educational activities (on all levels); art; librarianship; the art of dance; use of park space [1], [2]. Cultural volunteering takes the specificity of the target audience into account and is based on the principles of professionalism, tolerance, responsibility and partnership [3-5].

Since the 1990s, Russian cultural organizations have turned to practice of using the volunteers, fully aware of the importance of voluntary resources in the museum activities. Mostly it's museums that started inviting volunteers to help with the organization of various projects based on their development platforms. The main bases of cultural volunteering are Moscow and Saint Petersburg, where cultural institutions use volunteer work more capably than in other regions [6].

The main objectives of the cultural volunteering are preservation and promotion of cultural heritage, the formation of cultural identity, promotion of cultural facilities for young people, the development of common responsibility for the preservation of cultural heritage [7], [8].

\section{Methods}

In 1996, the State Hermitage Museum was one of the first museums in the country to launch volunteer projects. As a part of the Friends of the Hermitage Club volunteers helped foreign tourists to orient, answered questions and attracted visitors to the Friends Club. However, that work was irregular and had a temporary character. In 2003, Volunteer Service was created to assist in the celebration of the anniversary of St. Petersburg, which made it possible to take the volunteer activities to a new level and provide substantial assistance to the departments of the State Hermitage Museum during thelargescale commemorative events [9].

Areas of volunteer work at the Hermitage include:

1) Welcoming visitors and helping administrators in recreational areas -controlling the access to the rooms and the routes; monitoring (Hospitality Service, Tourism Sector, Social Research, Department of Development and Marketing Research, Security);

2) Assistance in conducting the scientific research - systematization and cataloging of storage objects, restoration, archeological excavations (Europe and Western Siberia archeology department, Furniture Restoration Workshop, Department of Chief Architect);

3) The translation of information materials, assistance in preparing the documents and publications; secretarial and courier 
work (IT Sector, Hospitality Service, Europe and Western Siberia archeology department, Press Service, Department of Development and Marketing Research);

4) Development and implementation of design projects presentation of multimedia projects; assistance in the conduct of correspondence and the use of modern means of communication and information technologies (Friends of the Hermitage Club, State Hermitage Storage Facility in Staraya Derevnya, Europe and Western Siberia archeology department, Research Library);

5) Participation in international educational programs, seminars and conferences and assistance in their organization; foreign language teaching and the organization of language practice (Hospitality Service, "School Centre" Teaching Department; Scientific Library);

6) Helping in the transportation of objects and holding the exhibitions, theatrical events and concerts (Tourism Sector, The Hermitage Music Academy, Hermitage Theatre, Department of Exhibit Transportation, Department of Western European Art, Research Library, and Logistics Department).

During the Service's existence schemes of cooperation with volunteers of the museum departments in priority areas of work were established, both in the Hermitage and outside of it. As an integral part of the internal life of the museum, volunteer service provides apprenticeships for students of Russian and foreign universities [10].

Year of the Culture, declared in 2014 in Russia, has ledto the bigger number of public events. City festivals have expanded the repertoire of urban cultural practices, with new audiences getting involved in the cultural life of the city and visiting the cultural institutions, which resulted in a massive engagement of volunteers. It is important to note that different types of events had pursued different goals. If for a citywide holiday it is important to get as many as possible people involved, providing a diverse and high-quality program, festival events meet the more specific objectives of the Ministry of Culture. Events related to the Year of Culture in Russia required the involvement of new creative forces in the work of cultural institutions; therefore, they have begun to actively involve volunteers in their activities. An active policy with regard to attracting volunteers, for example, is used by the organizers of cultural and educational action "Night at the Museum" which for several years has grown bigger in many Russian cities. Due to the increase in the number of participating museums, "Night at the Museum" is getting bigger every ear. For the implementation of various organizational and information tasks, participants are invited from various youth and volunteer projects [11].

The first experimental volunteer center for museums and galleries, using the successful experience of volunteering in the USA within the framework of the Moscow Department of Culture has opened at the State Museum of History of the Gulag. Volunteers offered to participate in the realization of exhibitions, lectures and concerts, working with archival documents, translate materials into foreign languages and to help people who suffered from Stalin's repressions and purges. At the ticked window and the museum site, you can fill out a volunteering form. Its purpose is capturing the range of interests and professional capacity of the candidate. Using this information, center staff communicates with the participants for the specific objectives of the program - for example, when the "wards" of the museum need volunteer assistance in dealing with legal issues. Socio-volunteer center of the Gulag Museum creates a special community of people who want to provide expert assistance to the museum and its audience in their spare time and offers creative and educational tasks to the volunteers. For example, gathering information from the books: the museum library has a large number of relevant publications for its employees and the task to find historical facts in the text and write them down. Volunteer Center is looking for people who will take the library memoirs and life stories of former prisoners and return them with notes relevant to the history of Stalinist repressions [12].
The museum plans to organize special lectures, workshops, film screenings and discussions for members of the volunteer community and introduce the volunteer card, which can get you discounts in the museum's café and bookshop and later - in the museum's partner sites.

The work of Polytechnic Museum's volunteers is an interesting experience in the field of cultural volunteering. In 2011, the Polytechnic Museum has worked with volunteers initially only for the large projects (" $360^{\circ}$ " Festival of Contemporary Scientific Film, Max Planck Tunnel), attracting mainly students and graduates of specialized universities. But in 2013, due to the reconstruction museum's historical building in the New Square, Polytechnic University acquired three new permanent addresses on the map of Moscow and increased the number of offers to the visitors and the number of volunteers, respectively. Following the unchanging principle of science popularization, the museum has become a real scientific and cultural institution that is attended visitors of all age groups every day. Weekly Polytech activities involve from 30 to 150 volunteers. Eventful life of the Polytechnic Museum at VDNKH and partner sites opens up many opportunities for volunteers from aid during the individual events - such as the scientific "Polytech" festival and festival of contemporary scientific film " $360^{\circ}$ ", a program of informal popular scientific conference "Science Fights", a range of educational events in museum's lectorium - to full participation in the life of the museum. You can try yourself as a consultant on interaction with the latest technology at the site of the main exhibition Polytech "Russia Can Do It" or to contribute to the "Children's University" project - additional education program for school children aged 8-11. Also Polytechnical Museum offers the opportunity to do an internship in any of its departments -from the Department of the Exhibition to the Development Group. Experience as a Polytech volunteer ensures familiarity with the basics of museum work, based on one of the largest sites with 140 years of history, insight into the process of the organization of huge scale exhibitions and educational events and development of personal and professional skills through participation in a special program on public speaking training and working with people.

The museum working schedule is built considering the free time of participating volunteers and may range from one to four shifts per week (more if wanted).

Volunteers help in all areas of museum activities:

1) Explainers at exhibitions and expositions - working with visitors and subjects / objects;

2) Assistants in children's classes (in research laboratories, lecture halls for the children, "Children's University").

3) Assistants in public museum events - lectures, workshops, performances («controlling the masses", advising, working with microphone, conducting polls).

4) Pro bono volunteers - experts in a particular field (journalists, photographers, teachers, and engineers) who come to the museum in their spare time on a certain event or remotely help to do some job.

5) Polytechnic library and fund volunteers - helping custodians during the tour: meeting the visitors, forming the groups, keeping the objects safe; helping in the library by cataloging the periodicals.

The volunteering program is actively promoted at the Darwin $\mathrm{Mu}-$ seum. Volunteers learn to greet and advise visitors, they get involved in the organizational support of the museum's activities, including the vernissages, conduction of the sociological studies (asking visitors questions), secretarial and courier work, promotion of the museum on the web. Volunteer himself/herself determines the time that can devote work in a museum, and coordinates it with his curator. The help is needed most often in the one-off events -exhibition openings, workshops and environmental holidays. The museum provides a volunteer pass for access to the sites.

You can also note the successful examples of volunteering in cultural institutions in other regions of Russia.

Association of Nizhnevartovsk Museum Volunteers is a voluntary public union of leaders and members of school museum staff. 
The association's purpose is to preserve the historical and cultural heritage through the formation of a united museum space and tight cooperation of the city school museums through the organization of joint seminars, conferences and field trips. The Association is committed to improving civic engagement of adolescents and young people through the museum study, sightseeing tours and other projects [13].

The objectives of the Association include:

- implementation of a multi-level weave of information streams interacting with each other: the museum will expand ties with the community to increase the reputation of the museum and its relevance;

- formation of new generation's morality, patriotism, a sense of responsibility for the fate of Russia, respect for the military and labor feats of the people;

- creation of a new environment and conditions for effective patriotic education of youth;

- Formation at teenager's objective approach to historical events in the life of the country;

- preservation of historical and cultural heritage by getting volunteers into the excursion and exhibition work;

- identification, compilation and improvement of methods and forms of work of school museums;

- coordination of the activities of the association members in informational, methodical, organizational and other areas.

The types of activities of the association include:

1) Organization of museum activity training;

2) The organization of thematic exhibitions, excursions, dedicated to the most significant events in the country, preparation and organization of conferences and other events;

3) Release of the final paper on the work done for the formation of information and analytical collection to share experiences of managers and volunteers of school museums.

This association aims to unite urban school museums to participate in the realization of common goals and programs on a voluntary basis.

Over the past two years, 50 students of city schools were trained in the organization of museum work in the school. Volunteers met were introduced to exhibition activities, visited the city museum and learned how to create public museums.

The «Pages of our Chita's History»

The «Pages of our Chita's History» project is implemented on the base of A.K. Kuznetsov Trans-Baikal Local History Museum. The target audience are guests of the Trans-Baikal and educational institutions of the capital.

The project aims are:

1) Creation of a volunteer guide team from among Chita's students for working with the city guests and local residents;

2) Enhancement of the future professional skills, forming the sense of the belonging to the local history in local youth through their involvement in voluntary activities;

3) Self-realization of young people in the creation of their own tours. Prospective areas: old Chita, religious Chita, scientific Chita, modern Chita etc.;

4) Increasing the prestige of the city of Chita in the eyes of local residents and visitors of Trans-Baikal Territory.

Together with the staff of the Local History Museum and the partnering travel agency, there are plans to organize a series of training workshops on conducting tours about history and architecture of the city and region. Implementation of this project will help in optimizing the interaction with city visitors: team of trained tour guides and volunteers will be able to organize cultural leisure after consultations with individual work schedule; they will have the opportunity to do internships in museums and tourist agencies of the city and acquire the necessary communication skills. The contact info of tour volunteers will be transferred to the education departments for the purpose of rapid communication with the students.

Implementation of the proposed project will spread the idea of youth's hospitality around the city and the region. Volunteer guides will be an integral part of all the major city events and will be worthy representatives of their schools.
"Museum Volunteer Landing" -is a project to create a volunteer camp at The State Memorial and Natural Preserve "Museum-estate of Leo Tolstoy "Yasnaya Polyana" [14].

The purpose of the project isto build a dedicated community around the world-famous Museum, consisting of people who want their unpaid labor to promote the preservation of the unique cultural and natural landscape of Yasnaya Polyana, where Tolstoy lived for most of his life.

The three volunteer shifts, each with its own goals, objectives and seasonal tasks, are planned throughout the year. Under the guidance of museum curators, participants of the volunteer camp take careof the seedlings in the nursery and fruit trees in the gardens, work on the museum's garden and in the greenhouse, clear the memorial forest and park areas, plant flowers and herbs in the central part of the estate, and much more.

The volunteer camp program is an acquaintance with the history and traditions of the estate of Tolstoy family; lectures and guided tours, theater and dance workshops, folk art classes, surveys and assistance to local residents, participation in museum festivals and cultural events.

Project objectives:

- Reducing the deficit of labor and financial resources for the conservation of the memorial homestead appearance

- Learning and exchange of Russian and foreign volunteer experience in the heritage preservation;

- Implementation of the participating volunteers' creative potential;

- Organization of seminars and trainings for volunteers;

- Overcoming the alienation within the local community, involvement in joint events and programs to increase loyalty and lower the dependency;

- The openness of the project - creation of a website, promotion in social networks, the organization of special events with the participation of the local population;

- Encouraging the volunteers - exclusive excursions, meetings with famous people, free access to the museum's activities, discounts and gifts;

- Providing charity care for the local elderly and socially vulnerable people.

The selection of museum volunteers is done through a variety of methods, such as interviews, questionnaires and probations. Anyone who wishes to volunteer is invited to fill in a questionnaire on the organization's website and familiarize with the basic requirements for volunteers.

Museums, in turn, create conditions for volunteer work, providing them with logistical, information and consulting support in the implementation of voluntary commitments.

Museums are turning to the practice of formation of competence model for volunteers (personal qualities and professional skills) involved in the organization and activities of the organization. Thus, according to the staff of the Museum, volunteers must have an interest in science and art, different communication skills and courtesy, since they have to work closely with numerous different types of the museum audience. One of the key requirements for the volunteers of the State Hermitage was the willingness to contribute to the development of the museum on a voluntary basis; willingness to participate in the internal life of the museum; ability to take responsibility for themselves, for museum visitors and the museum itself; readiness for rapid change of the operating conditions; willingness to follow the task management requirements, including work under the supervision of the authorities on the ground; teamwork ability, communication skills and ability to learn; respect for other cultures and races; basic educational training; physical and emotional health.

\section{Results}

Definition of the role of volunteers, development of their goals and communication issues largely depend on the models of organization 
of the work of volunteers used by cultural institutions [15]. Depending on the specific characteristics of employment are the following types of volunteers in the field of culture:

- Regular volunteers (adhere to specific hours per week).

- Project volunteers (short-term liabilities);

- Occasional volunteers (helping only during special cultural activities and events);

- Off-site volunteers (typically perform tasks at home);

- Micro-volunteers (very short terms);

- Groups of volunteers (families and friends);

- Employer-supported volunteers;

- Crowd-sorting volunteers.

Country museums highly value a system of rewards for volunteers that enhances the activity and the quality of volunteer work, more objectively evaluates the work performed by the degree of involvement in activities at different levels (for example, starting from the project until the curation), as well as helping to develop personal social qualities like discipline, responsibility for implementing the plans and tasks, integrity and etc. A bonus program for volunteers provides free museum entry, invitations to concerts and exhibitions, access to unique museum collections and educational programs of cultural institutions. Additional bonuses are special programs for public speaker training, communication and personal development. For example, Polytechnic Museum's "Volunteer Card" provides free admission to exhibitions and lectures throughout the year. To get a card, you must successfully complete a major Polytech team project or work for over two months in an exhibition. State Hermitage Museum in St. Petersburg plans to organize special lectures, workshops, film screenings and discussions for members of the volunteer community, as well as the release of a volunteer card, which can get you a discount in the café and museum bookshop, and in the future, in the partner sites. "Manege" Museum and Exhibition Association provides the following as a part of a bonus program for volunteers: participation in various activities of the Association "Manege"; thank you letters from the leadership of "Manege" Association; tickets for the exhibitions, invitations to exhibition openings; valuable experience of teamwork in largest museum and exhibition association. Bonuses from the State Center for Contemporary Art: letters of recommendation, a catalog of the current exhibition as a gift, free admission to events NCCA during the month. In gratitude for their active participation in the life of the Darwin $\mathrm{Mu}$ seum, volunteers are encouraged with commemorative certificates, discounts on souvenirs and printed materials, invitations to various events.

Involvement in voluntary practice in the field of culture promotes an effective disclosure and use of volunteers' social and cultural potential in the framework of the proposed project facilities. Today, working as a volunteer in project teams metropolitan cultural institutions; you can get a truly priceless experience in various spheres of activity, to get authoritative advice and a job perspective. As part of the proposed types of work, volunteers' immersion in the practice-oriented, socially meaningful activities of cultural institutions is provided, promoting the development of personal qualities.

The International "Intermuseum" Festival in Moscow is a unique platform for professional dialogue and demonstration of the achievements of Russian and foreign museums.

The priorities of the festival include:

1) The experience exchange and demonstration of new museum features in use with current practices and modern technologies in museums;

2) The improvement of museum and museum-type institutions strategies and methods of work, aimed at improving the socio-economic attractiveness of territories (regions, provinces etc), the preservation and improvement of territory's and population's cultural heritage.

The structure of the festival includes several thematic parts:

- Exposition part;

- Competition program;

- Business program

- Cultural program.
As part of the Festival's competition program, awards and prizes by Ministry of Culture of Russia, the Russian Committee of the International Council of Museums (ICOM Russia), the Union of Museums of Russia and others are awarded to participants.

In February 2015, Moscow's eight leading museums (the State Tretyakov Gallery, Polytechnical Museum, State Darwin Museum, Gulag History Museum, Moscow Museum of Modern Art, Multimedia Art Museum, The Museum of Moscow and the Museum of Modern Art "Garage") developed a special card which gives the right of free passage to the largest sites and the permanent exhibitions of museums participating in the program. Each museum provides its own volunteers with a registered card, valid for six months from the date of issuance. "Sputnik" Card is a way for museums to say "thank you" and, in turn, support the volunteers. Free admission to the exhibition is just the beginning, with the increase in number of loyalty program participants, volunteers will receive new bonuses and benefits from our potential partners.

\section{Discussion}

In 2015, Vladimir Potanin Foundation established the "The Best Museum Volunteer Project" award. The prize is awarded for the development of museum volunteer service project. The jury of the festival,along with the fund, considers the museum's experience of working with volunteers, volunteer projects that are already implemented, the direction in which the museum intends to continue volunteer service and whether the museum is interested in inviting colleagues to transfer experience. For example, a volunteer project of the Tretyakov Gallery was noted by the jury for the high level of professionalism and depth of study.

In February 2015, the city of Sochi held "First All-Russian Volunteer Forum." It featured most active distinguished leaders and activists of volunteer organizations involved in the systematic work on the development of volunteering in Russia, as well as representatives of regional authorities engaged in realization of the state youth policy in the Russian Federation.

As a result of the Forum, four priority directions of development of volunteering have been identified in Russia, one of which is cultural volunteering.

\section{Conclusion}

Analysis of the current state of the cultural volunteering has allowed identifying the key issues in the field of volunteerism.

1) The information vacuum around volunteering in the cultural sphere.

2) Lack of social order in the cultural volunteering (unavailability of cultural institutions to the use of volunteer work).

3) The lack of ready models of interaction between cultural institutions and volunteers at the main cultural venues.

4) Lack of regional development of the system and management of cultural volunteering.

5) The lack of defined volunteer status (volunteer book, benefits).

To solve the problems voiced need to create a favorable environment for the development of cultural volunteering, namely:

1) Creation of the cultural trend (theaters, museums, etc.).

2) Engaging the media about the cultural sites.

3) Creation of a "club" culture (regional, district, etc.).

4) Creation of "family club" model (courses for children and parents).

5) Formation of a single channel of information about cultural activities based on the "one window" principle (public services portal, social networking, regional media, etc.).

6) Create ready interaction models for cultural sites.

7) Development of the volunteer status («volunteer experience" as a practice).

Development of cultural volunteering in the region will contribute to: 
- Monitoring requests of regional cultural sphere, carried out through committees in the regions to identify the characteristics of the cultural life of the regions;

- Preparation of the current regulation of the cultural volunteering;

- The direction of "recommendation" letters to the regional committees on the priorities areas of the cultural volunteering;

- The implementation of simple projects as a launching pad;

- The formation of the grid activities with the staff of cultural institutions for the work with volunteers

Educational activities for cultural volunteering direction can be represented by the following measures:

- The organization of forums for volunteers (best practice, social engineering techniques);

- Creation a new chart of the index (courses, professional coach, opinion leaders, relevant speakers, new formats);

- Conducting outreach activities;

- Delegation of selection of participants to the forums and sessions to the professional communities;

- Delegation of public control;

- The creation of "interest clubs" and the new directions (graffiti);

- Support youth initiatives based around cultural sites;

- The annual cultural flash mobs in the Russian cities to combine the information space;

- The organization of forums and meetings in all regions for the exchange of the key models for working with volunteers (generalization of experience, trends, formulating the problems, opening new opportunities);

- $\quad$ Forums and meetings at the federal level for the partnership development (fostering good neighborly relations and the exchanging the positive experiences);

- Development of the annual theme (common agenda for all regional forums on cultural volunteering);

- $\quad$ The creation of a positive image for cultural volunteering (common symbols, symbols of individual projects);

- The development of cooperation with the art universities.

\section{References}

[1] Anderzhanova, Z. A., (2010). Spetsifika volonterskoy deyatelnosti v SSHA [Specificity of volunteer activities in the United States]. Social Policy and Sociology, 9, 38-55.

[2] Edwards, D., \& Graham M. (2006). Museum volunteers: A discussion of challenges facing managers in the cultural and heritage sectors. Australian Journal on volunteering, 11(1), 19-27.

[3] Goodlad, S., \& McIvor S. (1998). Museum volunteers: Good practice in the management of volunteers. London: Routledge.

[4] Gorlova, N. I., \& Krutitskaya, Ye. V. (2015a). Ekspertnaya otsenka sotsialnykh proektov. Osobennosti ekspertizy v sfere dobrovolchestva [Expert evaluation of social projects. Expertise features in the area of volunteering]. N.I.Gorlova (Ed.). Moscow: Publishing center of Sholokhov Moscow State University for the Humanities.

[5] Gorlova, N. I., \& Krutitskaya,Ye. V. (2015b). Rukovodstvo po sertifikatsii, monitoring $i$ otsenke deyatelnosti dobrovolcheskikh organizatsiy [Certification Guide, monitoring and evaluation activities of voluntary organizations]. Moscow: ITA "Perspective".

[6] Gorlova, N. I, \& Troska, Z. A. (2016). Osnovy volonterskogo menedzhmenta: rukovodstvo po keystekhnologiyam [Fundamentals of volunteer management. Guidelines for case-technologies]. Moscow: ITA "Perspective".

[7] Graham, M., \& Foley, M. (1998). Volunteering in an Urban Museums Service: A Definitional Reassessment'. In N. Ravenscroft, D. Phillips \& M. Bennett (Eds.), Tourism and Visitor Attractions, Leisure, Culture and Commerce (pp. 21-38). Eastbourne: Leisure Studies Association.

[8] Grönlund, H., Holmes, K., Kang, C., Cnaan, R. A., Handy, F., Brudney, J. L., Meijs, L. C. (2011). Cultural values and volunteering: A cross-cultural comparison of students' motivation to volunteer in 13 countries. Journal of Academic Ethics, 9(2), 87-106.
[9] Deery, M., Jago, L., \& Mair J. (2011). Volunteering for museums: the variation in motives across volunteer age groups" Curator: The Museum Journal, 54(3), 313-325.

[10] Handy, F., Cnaan, R. A., Hustinx, L., Kang, C., Brudney, J. L., Haski-Leventhal, Zrinscak, S. A cross-cultural examination of student volunteering: Is it all about résumé building? Nonprofit and Voluntary Sector Quarterly, 39(3), 498-523.

[11] Hirzy, E. C. (2007). Transforming Museum Volunteering: A Practical guide for engaging 21 st Century Volunteering. Bloomington, IN: Author House.

[12] Howlett, S., Machin, J., \& Malmersjo, G. (2005) Volunteering in museums, libraries and archives. London: IVR.

[13] Kemmelmeier, M., Jambor, E. E., \& Letner J. (2006). Individualism and good works: Cultural variation in giving and volunteering across the United States. Journal of Cross-Cultural Psychology, 37(3), 327 344.

[14] Orr, N. (2006). Museum volunteering: Heritage as 'serious leisure' International Journal of Heritage Studies, 12(2), 194-210.

[15] Osokina, L. M., Kamneva, V. P. (2010). Osnovy sotsialnoy raboty s invalidami po slukhu [Basics of social work with people with hearing disabilities]. Moscow: Lika. 